\title{
Penerapan Proses Keperawatan di Rumah Sakit
}

\author{
Lili Evalina
}

lili.evalina@gmail.com

\section{Latar Belakang}

Rumah sakit ialah suatu instansi kesehatan yang memiliki manfaat yang sangat banyak bagi masyarakat karena pelayanan didalamnya seluruhnya berkaitan dengan kuratif dan rehabilitatif(Adikoesoemo, 2012). Seluruh staff yang ada di rumah khususnya tenaga kesehatan melakukan pekerjaan nya sesuai dengan standar yang telah ditetapkan baik standar profesi, standar pelayanan rumah sakit, standar prosedur operasional yang berlaku, etika profesi, menghormati hak pasien, dan mengutamakan keselamatan pasien. Tenaga kesehatan yang ada dirumah terdiri dari tenaga medis dan penunjang medis, tenaga keperawatan, tenaga kefarmasian, tenaga manajemen rumah sakit dan tenaga non kesehatan.

Dalam suatu rumah sakit terdapat salah satu pelayanan yang mutlak sangat penting dan dibutuhkan oleh setiap pasien namun pelayanan nya harus diberikan oleh tenaga kesehatan profesional dibidangnya berupa pelayanan keperawatan(Kozier, 2013). Pelayanan keperawatan menjadi tugas seorang perawat dan merupakan bagian dari proses keperawatan dalam upaya memberikan setiap langkah asuhan keperawatan kepada pasiennya (Hidayat, 2012). Asuhan keperawatan sendiri ialah suatu bentuk pendekatan yang berguna untuk memecahkan suatu masalah dengan proses manajemen yang dilakukan oleh perawat namun tetap mematuhi standar yang berlaku(Bararah T, 2013).

Standar asuhan keperawatan menjadi suatu pedoman, tolak ukur ataupun landasan dari seluruh praktek yang dilakukan oleh perawat agar praktik yang dilakukannya mampu berjalan secara profesional, penuh etika, dan tanggung jawab(hardhi, 2016).Standar asuhan yang tercantum dalam Standar Praktik Klinis Keperawatan terdiri dari lima fase asuhan keperawatan: 1) Pengkajian; 2) Diagnosa; 3) Perencanaan; 4) Implementasi; dan 5) Evaluasi. Salah satu manfaat dari penerapan asuhan keperawatan yang baik adalah meningkatkan mutu dan kualitas pelayanan dalam bidang keperawatan (Budiono, 2016). 
Walaupun seluruh proses pelayanan keperawatan yang ada di Rumah sakit telah dilakukan sesuai standar secara profesional namun tetap masih ada permasalahan yang muncul di dalam pelayanan keperawatan di negara Indonesia ini seperti perawat yang hanya melakukan asuhan keperawatan yang sesuai standar ketika diawasi selanjutnya ketika praktik mandiri banyak yang tidak melakukannya karena terkesan rumit (Zulkarnain, 2017). Standar tersebut dapat dilihat dari kecepatan perawat saat menangani pasien, kemandirian bekerja, sikap dan perilakunya kepada pasien maupun sesama tenaga kesehatan, kehadiran kerja, terampil tidaknya dalam bekerja, serta sejauh mana pengetahuan yang dimiliki diterapkan saat menjalankan tugas yang diembannya (Fatmawati, 2018).

\section{Metode}

Metode yang digunakan dalam penulisan jurnal ini adalah metode kualitatif dengan pendekatan kajian pustaka. Dalam penelitian ini data yang digunakan berasal dari sumber - sumber dengan topik yang bersangkutan seperti dari jurnal keperawatan, buku, thesis, skripsi. Dalam arti lain dengan menggunakan kajian pustaka, maka apa yang dituliskan dalam jurnal ini merupakan hasil dari penelitian terdahulu yang membahas masalah yang sama. Dengan menggunakan metode kualitatif ini juga data yang disampaikan akan berbentuk penulisan dan penjabaran dan tidak dikemas secara statistik.

\section{Hasil}

Dalam penelitian Omy oini, dkk (2017) masalah yang ditekankan sebagai bahasan penting ialah mengenai gambaran pelayanan keperawatan yang dilakukan oleh perawat dengan mengacu 5 aspek yaitu tangibility, empathy, reliability, assurance, dan responsiveness. Lalu pada penelitian Antonia Nogo (2014) Fokusnya ditekankan secara teknis dengan melihat standar prose keperawatan dan pada hasil pelayanan nya kepada pasien yaitu terkait perencanaan dan hasil diagnosa terhadap pasien. Kemudian penelitian ketiga dari Husnul \& Yusuf (2018) dengan masalah penelitan pada ini lebih difokuskan pada tahapan asuhan keperawatan Pengkajian, Diagnosa, Perencanaan, Implementasi dan Evaluasi. 
Selanjutnya, penelitian dari Hendra Saputra (2014) proses keperawatan dan asuhan keperawatan yang dilakukan pada pasien ditekankan pada proses dukungan kepada pasien terkait masalah spiritual. Dan terakhir jurnal dari Mulyati dkk (2020) lebih difokuskan pada proses pelayanan keperawatan dalam hal ketersediaan perawat dalam melayani 24 jam dan juga kualitasnya didasarkan pada jumlah perawat yang sedang bertugas. Dari seluruh penekanan masalah tersebut terlihat bahwa seluruh fokusnya pada pelayanan keperawatan namun dalam bidang yang berbeda-beda.

Penerapan proses keperawatan di rumah sakit biasanya dikaitkan dengan asuhan keperawatan. Dalam praktiknya, perawat menggunakan pengetahuan dan kemampuan tentang proses keperawatan untuk mengkaji kesehatan klien, menentukan diagnosa, merencanakan asuhan keperawatan, menerapkan dan mengevaluasi tindakan keperawatan yang diberikan sehingga mencapai hasil yang memuaskan.

Penerapan proses keperawatan penting diterapkan di setiap rumah sakit karena menyangkut kualitas asuhan keperawatan untuk pasien. Jika proses keperawatan tidak sesuai, maka asuhan keperawatan yang didapatkan oleh pasien juga tidak sesuai dengan kondisinya. Proses keperawatan juga berkaitan dengan pemenuhan kebutuhan pasien selama di rumah sakit. Dengan terpenuhinya kebutuhan pasien, maka proses keperawatan yang ada di rumah sakit bisa dikatakan berhasil dan sesuai.

\section{Pembahasan}

Perawat yang bekerja pada suatu Rumah sakit pasti akan melakukan proses keperawatan baik itu mandiri atau mendampingi dokter. Proses keperawatan yang dilakukan oleh perawat sangat banyak dan mengacu pada 5 dimensi keperawatan yaitu tangibility, empathy, reliability, assurance, dan responsiveness. Pada dimensi reliability pasien telah puas telah proses pelayanan yang diberikan perawat karena perawat mau memberikan pelayanan 24 jam terkait dengan penjelasan mengenai tindakan dan prosedur yang akan dilakukan serta meminta ijin ketika akan melakukan tindakan terhadap pasien. Pada dimensi assurancepasien telah puas telah pelayanan perawat karna perawat langsung 
mengambil tindakan tanpa ada keragu-raguan. Lalu dimensi responsivenesslebih mengarah ke kemampuan perawat dalam memenuhi setiap keinginan pasien, perawat melakukan proses keperawatan dengan menanyakan keluhan pasien, memberi kesempatan pasien untuk bertanya, dan menanggapi permasalahan pasien.

Pada dimensi empathy perawat telah mampu memenuhinya karena selalu memperkenalkan diri sebelum memulai pemeriksaan dan menyapa pasien yang datang. namun pada dimensi tangibility banyak pasien yang tidak puas dengan proses keperawatan yang diberikan oleh perawat karena saat pasien rawat inap dan pasien ingin memanggil perawat dengan menekan bel, perawat lama tak kunjung datang, juga karena tidak adanya kotak saran disetiap kamar, tidak menggunakan jam tangan untuk menghitung tetesan infus dan juga perawat yang terkesan ceroboh karena tidak menggunakan stetoskop untuk mengukur tandatanda vital (Omy Oini, 2017). Walaupun penelitian ini menggunakan 5 dimensi sebagai acuannya namun memiliki kesamaan dengan penelitian Mulyati (2020) dalam aspek reliability yaitu pemberian layanan dalam 24 jam oleh perawat dan juga sama-sama melihat respon kepuasaan pasien terhadap proses keperawatan yang diberikan.

Dalam penelitiannya, dapat digambarkan bahwa perawat harus mampu memberikan pelayanan selama 24 jam dengan pasien dan juga berinteraksi secara dominan(Mulyati, 2020). Karena konstribusi perawat yang dianggap besar, maka peneitian ini berupaya mengembangkan kemampuan perawat untuk lebih meningkatkan kualitasnya dengan cara memberikan pelatihan caring. Pelayanan caring tersebut akan digunakan untuk meningkatkan profesionalisme perawat agar tercipta pelayanan yang berkualitas dan memuaskan karena fokusnya menggali kepuasaan pasien dengan cara memenuhi kebutuhan maupun harapan yang diinginkan oleh pasien (Hardiansyah, 2018).

Kedua penelitian diatas mengacu pada aspek teknik Proses keperawatan berbeda dengan penelitian Hendra (2014) yang mencoba menggali proses keperawatan dari segi asuhan keperawatan yang diberikan oleh perawat. Penelitiannya menggambarkan proses keperawatan dari lima fase asuhan 
keperawatan yaitu Pengkajian, Diagnosa, Perencanaan, Implementasi dan Evaluasi. Pada fase pengkajian perawat memberikan pelayanan keperawatan dengan cara menanyakan kepada pasien terkait kebiasaan sholat, berdoa, dan berdzikir, lalu pada fase diagnosa perawat akan mencoba menanyakan keselitan saat sholat, berdoa, dan berdzikir serta menawarkan dukungan dan bantuan kepada pasien.

Pada fase intervensi, perawat akan mencoba memberikan pelayanan kepada pasien terkait untuk mendukung proses keperawatan dengan menyampaikan halhal yang harus dilakukan dan tidak boleh dilakukan selama sholat, berdoa, dan berdzikir. Selain terkait spiritual dukungan dan bentuk semangat yang diberikan kepada pasien juga murni diberikan oleh perawat agar tingkat kesembuhan pasien dirumah sakit meningkat dan lebih cepat. Selanjutnya di fase implementasi perawat akan selalu mengingatkan pasien untuk sholat, berdoa, dan berdzikir. Selain itu, perawat akan memberikan motivasi kepada pasien agar kondisi kesehatannya membaik dan memberikan dukungan mental agar tidak larut dalam kesedihan karena sakit.

Terakhir di fase evaluasi, perawat akan mencoba menanyakan kembali terkait sholat, berdoa, dan berdzikir, apakah selama beberapa hari tersebut pasien akan selalu ingat dan melakukannya atau tidak. Perawat juga mulai menanyakan kembali apakah pelayanan keperawatan yang diberikan termasuk perhatiannya memberikan rasa nyaman kepada pasien atau tidak (Saputra, 2014). Penelitian tersebut memiliki kesamaan dengan penelitian Husnul dan Yusuf (2018) karena berkaitan dengan lima fase asuhan keperawatan dalam rangka menjalankan proses keperawatan. Namun kedua penelitian tersebut memiliki perbedaan dalam hal topik yang diangkatnya penelitian Hendra (2014) mengangkat topik mengenai keadaan spiritual pasien berbeda dengan peneitian Husnul dan Yusuf (2018) yang mengangkat topik lebih umum yaitu mengenai medis atau kesehatan pasien selama dirawat di Rumah Sakit.

Asuhan keperawatan yang diteliti dengan topik medis menggambarkan 5 fase dalam proses keperawatan. Fase pengkajian, perawat sudah melakukannya dengan baik karena perawat di Rumah Sakit tersebut telah memiliki kemampuan 
pengkajian yang dibuktikan dengan berhasilnya melakukan proses pengumpulan data, pengelompokan data, dan melakukan analisis untuk menentukan diagnosis. Seluruh kegiatan dalam mendapatkan data tersebut dilakukan perawat dengan cara anamnesa, observasi, pemeriksaan fisik, serta pemeriksaan penunjang. lalu, sumber data adalah pasien, keluarga atau orang yang terkait, tim kesehatan, rekam medik, dan catatan lain masa lalu, status kesehatan pasien saat ini, status bio, psiko, sosial spiritual, respon terhadap terapi(Husnul Wirdah, 2018).

Fase diagnosa juga telah dilaksanakan perawat dengan baik karena telah mampu menentukan prioritas masalah pasien dengan klarifikasi dan analisis data dari pengkajian keperawatan. Lalu fase perencanaan, perawat telah mampu melakukan intervensi kepada pasien sesuai dengan rencana yang diambil dan menjadikan rencana keperawatan yang diambil sebagai media komunikasi mengenai asuhan keperawatan antar perawat dengan pasien. Pada fase selanjutnya yaitu implementasi, perawat seharusnya melakukan pendokumentasian tindakan namun dalam penelitian ini kegiatan perawat dinilai kurang baik (Husnul Wirdah, 2018). Hal tersebut kemungkinan disebabkan oleh motivasi maupun kemampuan dari perawat (Biki, 2015).

Terakhir fase evaluasi, perawat melakukan pengkajian ulang yang melibatkan pasien dengan keluarga dengan membandingkan antara rencana yang telah dibuat dengan intervensi yang telah dilakukan. Penelitian terakhir memiliki perbedaan dengan keempat penelitian yang telah dilakukan review dimana penelitian ini lebih melihat mengenai standar yang diterapkan dalam proses keperawatan di Rumah Sakit tersebut. Penelitian terakhir ini dilakukan oleh Antonia Nogo (2014), proses keperawatan yang dilakukan di penelitian ini berupa proses pengkajian dan pencatatan hasilnya dengan hasil bahwa perawat tidak melakukan proses keperawaan dengan baik karena diagnosa belum dilakukan secara standar, Implementasi tugas dan tanggung jawab umumnya belum sesuai SOP, kurang memperhatikan tindakan pencegahan infeksi, dan tidak melibatkan klien dan keluarganya secara maksimal. Evaluasimemang dilakukan namun tidak sesuai standar (SOAP). Dokumentasi kerja sudah dilakukan dengan segera, namun tidak dalam bentuk SOAP (Nogo, 2014). 
Penelitian Antonia Nogo (2014) juga memiliki kesamaan dengan penelitian Hendra (2014) dan Husnul dan Yusuf (2018) dari segi penerapan asupan keperawatan. Pada fase pengkajian telah dilakukan dengan baik, namun pada fase diagnosa terdapat sedikit yang tidak sesuai standar yaitu tidak adanya pencatatan komponen diagnosa. Fase perencanaan telah dilakukan tapi tidak semuanya sesuai standar. Fase implementasi terdapat beberapa yang belum sesuai standar SOP yaitu pada kurang perhatiannya pada masalah mencegah infeksi dan sterilnya alat serta keterlibatan anggota keluarga pasien. Untuk fase evaluasi sudah dilakukan sesuai dengan SOAP walaupun proses pendokumentasian tidak dilakukan segera setelah proses keperawatan dilakukan.

\section{Penutup}

Dalam melaksanakan tugasnya sebagai perawat, diperlukan suatu proses keperawatan yang sistematis. Proses keperawatan terbagi menjadi 2 jenis yaitu berdasarkan 5 dimensi keperawatan berupa tangibility, empathy, reliability, assurance, dan responsivenessdan fase keperawatan berupa Pengkajian, Diagnosa, Perencanaan, Implementasi dan Evaluasi. Dan dapat diambil kesimpulan bahwa penerapan proses keperawatan seharusnya tidak hanya melibatkan perawat namun juga pasien dan juga membutuhkan dukungan keluarganya. Proses keperawatan yang dilakukan oleh perawat di Rumah Sakit secara keseluruhan difokuskan pada pelayanan kepada pasien baik dalam hal perawatan maupun teknis pengobatan yang dilakukan sesuai dengan standar 


\section{Daftar Pustaka}

Adikoesoemo, S. (2012). Manajemen Rumah Sakit. Jakarta: Pustaka Sinar Harapan.

Bararah T, d. J. (2013). Asuhan Keperawatan Panduan Lengkap Menjadi Perawat Professional. Jakarta: Prestasi Pustakaraya.

Biki, P. (2015). Gambaran Kinerja Perawat dalam Memberikan Asuhan Keperawatan di Ruang Interna di RSUD PROF. DR.H.Aloei Saboe Kota Gorontalo. Jurnal Keperawatan Universitas Negeri Gorontalo, 1-9.

Budiono. (2016). Konsep Dasar Keperawatan. Jakarta: Kementrian Kesehatan Republik.

Fatmawati, A. (2018). Pengaruh Pelayanan Asuhan Keperawatan Terhadap Kepuasan Pasien di Puskesmas Takalala Kabupaten Soppeng. MIRAI: Journal of Managament, 1 (2). 33-57.

hardhi, A. \&. (2016). Asuhan Keperawatan Praktis Berdasarkan PenerapanDiagnosa Nanda, Nic, Noc Dalam Berbagai Kasus Jilid 1. Yogyakarta: Mediaction.

Hardiansyah. (2018). Kualitas Pelayanan Publik: Konsep, Dimensi, Indikator, dan Implementasinya. Gava Media, https://doi.org/10.1163/1571808512341263.

Hidayat, A. A. (2012). Pengantar Konsep Dasar Keperawatan. Jakarta: Salemba Medika.

Husnul Wirdah, M. Y. (2018). Penerapan Asuhan Keperawatan Oleh Perawat Pelaksana Di Rumah Sakit Banda Aceh. Jurnal Universitas Syiah Kuala, $1-7$.

Kozier, B. (2013). Buku Ajar Fundamental Keperawatan; Konsep, Proses dan Praktik edisi 7. Jakarta: EGC.

Mulyati, E. S. (2020). Tingkat Kepuasan Pasien Dalam Menerima Pelayanan Asuhan Keperawatan. Jurnal Keperawatan, Volume 12 No 1, Hal 57 - 62, Maret 2020.

Nogo, A. (2014). Kinerja Perawat Dalam Penerapan Standar Asuhan Keperawatan Di Rumah Sakit Umum Daerah Naibonat Kabupaten Kupang. Jurnal Penelitian, Volume 18, No. 1, November 2014, hlm. 62-66.

Omy Oini, R. K. (2017). Tingkat Kepuasan Pasien Terhadap Pelayanan Keperawatan Di Unit Rawat Inap. Nursing Current, Vol. 5 No. 2, Juli 2017 - Desember 2017, halaman 50 - 60. 
Saputra, H. (2014). Hubungan Penerapan Asuhan Keperawatan Dengan Pemenuhan Kebutuhan Spiritual Pasien di Ruang Rawat Inap Kelas III RS PKU Muhammadiyah Ygyakarta. Jurnal Stikes Aisyiyah Yogyakarta, 1-19.

- Simamora, R. H. (2019). Development of Guidelines for Applying appropriate Patient Identification to Achieve Patient Safety Goal

INC2019 12th International Nursing Conference. 2019.10455 - 455 (1 pages) UCI (KEPA) : I410-ECN-0101-2019-512-001224337

Simamora. R. H. (2008) The correlation of ward chief's giving direction and command and the performance of on-duty nurses at Jember dr. Subandi general hospital inpatient wards. Jurnal Administrasi dan Kebijakan Kesehatan, (https://fkm.unair.ac.id/jurnal-administr)

Zulkarnain. (2017). Analisis Pelaksanaan Fungsi Manajemen Pengarah Kepala Ruangan dengan Kinerja Perawat dalam Menerapkan Asuhan Keperawatan di Ruang Rawat Inap RSUD Bima. JISIP, 1 (2). 229-255. 